\title{
Effect of $\beta$-Hydroxybutyrate on Whole-Body Leucine Kinetics and Fractional Mixed Skeletal Muscle Protein Synthesis in Humans
}

\author{
K. Sreekumaran Nair, Stephen L. Welle, David Halliday,* and Robert G. Campbell \\ Department of Medicine, University of Rochester School of Medicine and Dentistry, Rochester NY 14603; \\ and the *Nutrition Group, Clinical Research Centre, Harrow HAI 3UJ, United Kingdom
}

\begin{abstract}
Because intravenous infusion of $\beta$-hydroxybutyrate $(\beta-\mathrm{OHB})$ has been reported to decrease urinary nitrogen excretion, we investigated in vivo metabolism of leucine, an essential amino acid, using $\mathrm{L}-\left[1-^{13} \mathrm{C}\right]$ leucine as a tracer during $\beta-O H B$ infusion. Leucine flux during $\beta$-OHB infusion did not differ from leucine flux during normal saline infusion in nine normal subjects, whereas leucine oxidation decreased $18-41 \%($ mean $=30 \%)$ from 18.1 $\pm 1.1 \mu \mathrm{mol} \cdot \mathrm{kg}^{-1} \cdot \mathrm{h}^{-1}(P<0.01)$, and incorporation of leucine into skeletal muscle protein increased 5-17\% (mean $=10 \%)$ from $0.048+0.003 \% / h(P<0.02)$. Since blood $\mathrm{pH}$ during $\beta-O H B$ infusion was higher than the $\mathrm{pH}$ during saline infusion, we performed separate experiments to study the effect of increased blood pH on leucine kinetics by infusing sodium bicarbonate intravenously. Blood pH during sodium bicarbonate infusion was similar to that observed during the $\beta-O H B$ infusion, but bicarbonate infusion had no effect on leucine flux or leucine oxidation. We conclude that $\beta-O H B$ decreases leucine oxidation and promotes protein synthesis in human beings.
\end{abstract}

\section{Introduction}

Conservation of protein is a vital metabolic adaptation for survival during prolonged fasting $(1,2)$. It has been proposed that protein conservation during fasting is related to ketosis (2, 3). Furthermore, when ketones displace glucose as a primary metabolic fuel for brain, the need for amino acid precursors for gluconeogenesis decreases and therefore protein breakdown decreases (2-4). This hypothesis is supported by the demonstration of decreased glucose production rate in humans (5) and in pigs (6), and a decrease in urinary excretion of nitrogen in fasted human subjects during intravenous infusion of $\beta$-hydroxybutyrate $(\beta-\mathrm{OHB})^{1}(7)$. Improvement of nitrogen retention in postoperative patients in proportion to their hyperketonemia (8) lends additional support to the hypothesis.

Dr. Campbell's present address is General Clinical Research Center, Cornell University Medical College and New York Hospital, New York, NY 10021.

Address reprint requests to Dr. Nair, Endocrine Unit, Monroe Community Hospital, 435 East Henrietta Road, Rochester, NY 14603.

Received for publication 24 April 1987 and in revised form 4 December 1987.

1. Abbreviations used in this paper: FMPS, fractional muscle protein synthesis; KIC, $\alpha$-ketoisocaproate; $\beta$-OHB, $\beta$-hydroxybutyrate.

J. Clin. Invest.

(c) The American Society for Clinical Investigation, Inc.

0021-9738/88/07/0198/08 \$2.00

Volume 82, July $1988,198-205$
In order to study the mechanism of nitrogen conservation during ketosis, Miles et al. (9) infused sodium-DL- $\beta$-OHB intravenously for $3 \mathrm{~h}$ in normal volunteers and measured in vivo leucine kinetics. They failed to demonstrate any effect of $\beta-O H B$ on leucine flux, indicating that $\beta-O H B$ does not decrease proteolysis. However, these results do not preclude the possibility that $\beta$-OHB inhibits protein losses by causing more of the free amino acids to be incorporated into protein rather than oxidized. In the present study we have examined the effect of $\beta-\mathrm{OHB}$ on leucine flux, oxidation, and incorporation into skeletal muscle protein, using $L-\left[1-{ }^{13} \mathrm{C}\right]$ leucine as a tracer. $\beta-O H B$ is known to affect the secretions of a variety of hormones, such as insulin and glucagon, and also alter the plasma concentrations of glucose and free fatty acids (5). The above hormones and substrates could affect protein metabolism, and therefore we considered the possibility that the effect of $\beta-O H B$ on leucine metabolism is secondary to the changes in hormones or other substrates. Plasma concentrations of the relevant hormones and substrates were also measured during the study period.

\section{Methods}

Subjects. We studied 13 normal healthy subjects whose data are given in Table I. The protocol for this study and the consent form were approved by the Human Investigation Committee of the University of Rochester School of Medicine and Dentistry. All subjects gave their informed consent before any procedures were performed at the Clinical Research Center (CRC) of the University of Rochester.

Materials. $\mathrm{L}-\left[1-{ }^{13} \mathrm{C}\right]$ leucine (99 atom \% excess), $\left[{ }^{13} \mathrm{C}\right]$ sodium bicarbonate ( 98 atom \%), and D-[6,6 $\left.6^{2} \mathrm{H}_{2}\right]$ glucose $(98$ atom \%) were obtained from Cambridge Isotope Laboratories Inc. (Woburn, MA). SodiumDL- $\beta$-OHB (Sigma Chemical Co., St. Louis, MO) was prepared as an isotonic solution in sterile water and neutralized to $\mathrm{pH}$ 6.8-7.4 with $\mathrm{HCl}$. All solutions were dissolved in sterile normal saline solutions with sterile precautions, passed through $0.22-\mu \mathrm{m}$ filters (Millipore Corp., Bedford, MA) and tested to be pyrogen free before infusion into our subjects.

Protocols. Two separate studies were performed at a 3-9-wk interval in subjects A-I $(n=9)$. One study was performed to measure the effect of $\beta-O H B$ infusion on leucine metabolism, and the other was performed with normal saline infusion (control experiment). In two subjects, the $\beta-\mathrm{OHB}$ infusion was done first, whereas in everyone else the normal saline infusion was given first. The preparation of the subjects before each of the studies was the same. They were admitted to the University of Rochester CRC 3 d prior to the study, during which they were kept on a weight-maintaining diet (composition as percentage of calories from carbohydrate/fat/protein $=45: 40: 15$ ).

All studies were performed after an overnight fast. A retrograde catheter was inserted into a dorsal hand vein and kept open by infusion of normal saline. This hand was kept in a hot box $\left(70^{\circ} \mathrm{C}\right)$ to collect arterialized venous blood samples (10). Two other forearm veins were catheterized in the contralateral arm to infuse $\beta-O H B$ or normal saline and the tracers.

A priming dose of $\mathrm{L}-\left[1-{ }^{13} \mathrm{C}\right]$ leucine $(7 \mu \mathrm{mol} / \mathrm{kg})$ and $\left[{ }^{13} \mathrm{C}\right]$ sodium bicarbonate $(0.2 \mathrm{mg} / \mathrm{kg})$ and $\left[6,6^{2} \mathrm{H}_{2}\right]$ glucose $(14 \mu \mathrm{mol} / \mathrm{kg})$ was given 
Table I. Subject Data

\begin{tabular}{ccccccr}
\hline Subject & Age & Sex & Weight & Height & Wt/Ht ${ }^{2}$ & Diet \\
\hline & $y r$ & & $k g$ & $c m$ & $k g / m^{2}$ & $k c a l / d$ \\
A & 21 & M & 80 & 167.0 & 28.7 & 2,545 \\
B & 21 & M & 78 & 180.4 & 24 & 3,146 \\
C & 28 & M & 73 & 193.4 & 19.5 & 3,316 \\
D & 30 & M & 67 & 173.1 & 22.3 & 2,615 \\
E & 28 & M & 87 & 186.0 & 25.1 & 3,568 \\
F & 20 & M & 72 & 178.2 & 22.6 & 3,033 \\
G & 25 & M & 73 & 173.5 & 24.3 & 2,498 \\
H & 28 & F & 76 & 177.3 & 24.2 & 2,595 \\
I & 21 & F & 61 & 162.3 & 23.2 & 2,124 \\
J & 23 & F & 66 & 167.4 & 24.6 & 2,278 \\
K & 24 & F & 66 & 173.7 & 21.9 & 2,565 \\
L & 26 & M & 75 & 168.8 & 26.3 & 2,814 \\
M & 35 & F & 51 & 164.4 & 18.9 & 2,057 \\
Mean & 25 & & 71 & 174.3 & 23.5 & 2,704 \\
\pm SEM & 1 & & 3 & 2.4 & 0.7 & 126 \\
\hline
\end{tabular}

and then a continuous infusion of $L-\left[1-^{13} \mathrm{C}\right]$ leucine $(7.6$ $\left.\mu \mathrm{mol} \cdot \mathrm{kg}^{-1} \cdot \mathrm{h}^{-1}\right)$ and $\left[6,6^{2} \mathrm{H}_{2}\right]$ glucose $\left(11.5 \mu \mathrm{mol} / \mathrm{kg}^{-1} \cdot \mathrm{h}^{-1}\right)$ was given for $8 \mathrm{~h}$ at a constant rate using a volumetric infusion pump. The accuracy of the infusion pump was checked by weighing the infusate bag at the beginning and at the end of the timed infusions. All subjects received either a sodium DL- $\beta$-OHB infusion $\left(12.5 \mu \mathrm{mol} \cdot \mathrm{kg}^{-1} \cdot \mathrm{min}^{-1}\right)$ or a similar volume of normal saline. During the first $10 \mathrm{~min}, 375$ $\mu \mathrm{mol} / \mathrm{kg}$ of sodium, DL- $\beta-\mathrm{OHB}$ was given as a priming dose.

Prior to the priming dose of $\mathrm{L}-\left[1-{ }^{13} \mathrm{C}\right]$ leucine a percutaneous needle biopsy was taken from a quadriceps muscle (11), using a University College Hospital muscle biopsy needle (Shrimpton \& Fletcher, Reddich, England). Muscle biopsies were not performed in two female subjects (subjects I and $\mathrm{J}$ in Table I) because they declined to repeat this procedure after one study each. The muscle specimen was immediately frozen in liquid nitrogen. A second muscle biopsy was performed at $8 \mathrm{~h}$ after $\left[{ }^{13} \mathrm{C}\right]$ leucine infusion was started. These samples were then freeze-dried to constant weight and rendered fat free, and analyzed as described below.

Blood and expired air samples for isotopic analysis were taken before the infusion and then every $h$ until $6.5 \mathrm{~h}$. Blood and expired air samples were taken every 15 min during the last $1.5 \mathrm{~h}$. The separated plasma samples were freeze-dried and these freeze-dried plasma samples and air samples in vacutainer tubes were shipped to the CRC, Harrow, England for isotopic analysis.

Carbon dioxide production was continuously measured for $1.5 \mathrm{~h}$ each between 3-4.5 and 6-7.5 h, respectively, using an open circuit indirect calorimeter, as previously described (12).

Since infusion of sodium DL- $\beta-O H B$ increased blood $\mathrm{pH}$, we infused sodium bicarbonate solution equimolar to the $\beta$-OHB intravenously in seven subjects, to separate the effect of $\beta$-OHB from that of $\mathrm{pH}$ changes. Subjects $\mathrm{A}, \mathrm{D}$, and $\mathrm{E}$ received sodium bicarbonate, saline, and $\beta-O H B$ infusions, whereas subjects $J, K, L$, and $M$ received only saline and sodium bicarbonate infusions. The study design for sodium bicarbonate infusion was exactly the same as that for $\beta-O H B$ infusion, except that no muscle biopsies were taken in this experiment.

Sample analysis. Plasma $\alpha$-ketoisocaproate (KIC) concentration and $\left[{ }^{13} \mathrm{C}\right] \mathrm{KIC}$ enrichment were measured by selected ion-monitoring gas chromatography-mass spectrometry under chemical ionization conditions after conversion as previously described (13). Expired air ${ }^{13} \mathrm{CO}_{2}$ was measured using an isotope ratio mass spectrometer $(14,15)$.

The freeze-dried muscle samples were treated with $3 \mathrm{M}$ sodium hydroxide and mixed muscle protein was extracted. The protein was then hydrolyzed in $6 \mathrm{M} \mathrm{HCl}$ at $105^{\circ} \mathrm{C}$ for $18 \mathrm{~h}$ the resulting amino acids derivatized and isolated by means of standard preparative gas chromatography. After hydrolysis of the leucine ester to the free amino acids, it was treated with ninhydrin to liberate $\mathrm{CO}_{2}$ from the carboxyl group. The released carbon dioxide was transferred to a glass "finger tube" for direct introduction into the isotope-ratio mass spectrometer to determine the ${ }^{13} \mathrm{CO}_{2} /{ }^{12} \mathrm{CO}_{2}$ ratio (15).

Calculations. Since KIC is the precursor of leucine oxidation, leucine oxidation was calculated using $\left[{ }^{13} \mathrm{C}\right] \mathrm{KIC}$ as the precursor pool as previously described (16). Leucine flux was calculated from plasma $\left[{ }^{13} \mathrm{C}\right] \mathrm{KIC}$ at steady state, which was assumed to reflect intracellular $\left[{ }^{13} \mathrm{C}\right]$ leucine abundance (17-19). Direct measurements in humans (17) and rats (18) demonstrate that plasma KIC labeling represents intracellular leucine labeling more closely than plasma leucine labeling. Studies in humans using the reciprocal pool model also support the use of plasma KIC labeling as an index of intracellular leucine labeling (19). The difference between leucine flux and leucine oxidation is the nonoxidative protion of leucine flux. Since leucine disappears from the free leucine pool either by irreversible oxidation or by incorporation into protein, the nonoxidative portion of leucine flux in steady state reflects the protein synthesis rate $(20,21)$. Glucose production rate was measured as previously described (22).

Fractional skeletal muscle protein synthesis (FMPS) rate was calculated from the increase of $\left[{ }^{13} \mathrm{C}\right]$ leucine in skeletal muscle protein (mixed) during an 8-h continuous infusion of $\mathrm{L}-\left[1-{ }^{13} \mathrm{C}\right]$ leucine. For calculation of FMPS, $\left[{ }^{13} \mathrm{C}\right] \mathrm{KIC}$ enrichment in plasma during the study period was considered to represent the precursor pool from which $\left[{ }^{13} \mathrm{C}\right]$ leucine was incorporated into protein. FMPS $=\left(L_{\mathrm{Em}} \times 100\right) /\left(L_{\mathrm{Ep}}\right.$ $\times 8)=\% / \mathrm{h}$, where $L_{\mathrm{Em}}$ represents the increment in $\left[{ }^{13} \mathrm{C}\right]$ leucine abundance in skeletal muscle protein from 0 to $8 \mathrm{~h}$ (atom percent excess) and $L_{\mathrm{Ep}}$ represents mean plasma $\left[{ }^{13} \mathrm{C}\right] \mathrm{KIC}$ abundance during the $8-\mathrm{h}$ study period.

Even though leucyl tRNA is the immediate precursor pool for protein synthesis, leucyl tRNA could not be measured from small muscle samples obtained from human subjects. Studies in rats demonstrated that specific activity free leucine reflects specific activity of leucyl tRNA in lung tissue (23). Skeletal muscle cell preparations demonstrated that the free leucine pool determines the leucyl tRNA labeling for protein synthesis (24). Studies in the cardiac muscle of rats indicate that $\mathrm{TRNA}$ has a rapid turnover and reaches a rapid equilibrium with amino acid precursor pool (25). Thus the labeling of KIC is quite likely to be a good index of the labeling of tRNA.

Plasma concentrations of glucose were measured using an autoanalyzer (Beckman Instruments, Inc., Fullerton, CA), $\beta$-OHB was measured by enzymatic technique (26), and free fatty acids were measured by a colorimetric technique (27). Plasma insulin was assayed by a commercial radioimmunoassay kit (Cambridge Nuclear, Billerica, MA), radioimmunoassay of glucagon was done using $30 \mathrm{~K}$ antiserum (28), C-peptide was assayed using specific C-peptide antibody (Guildhay, University of Surrey, Kent, England) with a double-antibody technique (29), cortisol was measured by radioimmunoassay using a

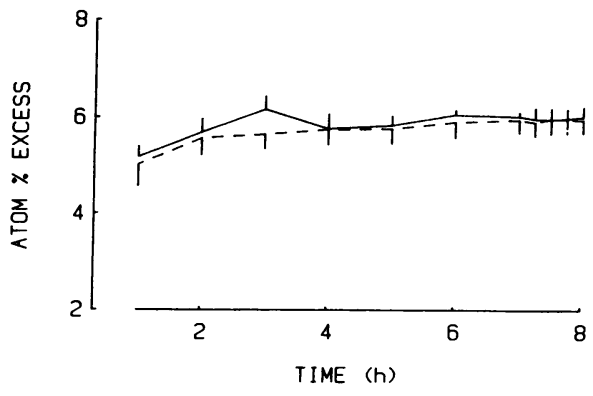

Figure 1. Plasma $\left[{ }^{13} \mathrm{C}\right] \mathrm{KIC}$ enrichment (atom percent excess) during $\beta$-OHB $(|-|)$ and saline $(|---|)$ infusion was not different. 
Expired $\mathrm{Air}^{13} \mathrm{CO}_{2}$

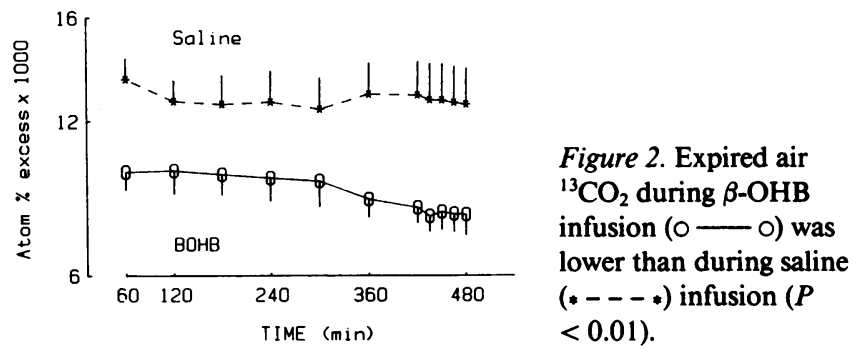

commercial kit (Diagnostic Products Corp., Los Angeles, CA), and epinephrine and norepinephrine were measured using a radioenzymatic assay (30). Amino acids were assayed by HPLC with fluorometric detection, after pre-column derivatization with 0 -pthalaldehyde/2mercaptoethanol (31).

Data analysis. Paired $t$ tests were employed to investigate whether observed differences between the leucine kinetics during $\beta-\mathrm{OHB}$ or sodium bicarbonate infusion and during the saline infusion were statistically significant. To assess the effect of $\beta-\mathrm{OHB}$ infusion on hormones and substrates, a two-way analysis of variance was performed with infusate and time as the two factors (BMDP Statistical Software, University of California, Berkeley). The statistical significance of differences between individual means was determined by the NewmanKeuls test (32). Regression analysis was done to demonstrate correlation between nonoxidative portion of leucine flux and FMPS.

\section{Results}

Leucine kinetics. Plasma $\left[{ }^{13} \mathrm{C}\right] \mathrm{KIC}$ enrichment is given in Fig. 1. $\left[{ }^{13} \mathrm{C}\right] \mathrm{KIC}$ enrichment was not different between the $\beta-\mathrm{OHB}$ and saline infusion, whereas ${ }^{13} \mathrm{CO}_{2}$ enrichment during $\beta$-OHB infusion was lower than ${ }^{13} \mathrm{CO}_{2}$ enrichment during saline infusion $(P<0.01$, Fig. 2). Leucine flux and leucine oxidation were calculated from $\left[{ }^{13} \mathrm{C}\right] \mathrm{KIC}$ and ${ }^{13} \mathrm{CO}_{2}$ values between 6.5 and $8 \mathrm{~h}$. During this period isotopic enrichment of $\left[{ }^{13} \mathrm{C}\right] \mathrm{KIC}$ and ${ }^{13} \mathrm{CO}_{2}$ did not change significantly, indicating steady state.

Leucine flux during $\beta$-OHB infusion was not different from leucine flux during saline infusion, whereas leucine oxi- dation during $\beta$-OHB infusion was lower than oxidation during saline infusion by an average of $30 \%(18-41 \%)(P<0.01$, Table II). The nonoxidative portion of leucine flux during the $\beta$-OHB infusion was higher (3-45\% with an average of $11.5 \%$ ) than it was during saline infusion $(P<0.02)$. Blood $\mathrm{pH}$ was higher during $\beta$-OHB infusion than it was during saline infusion $(P<0.01$, Table II). FMPS during the $\beta$-OHB infusion was higher (5-17\% with an average of $10 \%)$ during the $\beta-O H B$ infusion than during saline infusion $(P<0.02$, Fig. 3).

The precision of our measurement of $\left[{ }^{13} \mathrm{C}\right]$ leucine in muscle protein was evaluated by performing duplicate measurements of four quadriceps muscle biopsy specimens in normal human beings. Variation was $<1 \%$ in all cases. The reproducibility of measurements was determined in 10 subjects by measuring $\left[{ }^{13} \mathrm{C}\right]$ leucine incorporation into skeletal muscle protein of different muscle samples taken from the same muscle group and processed separately. The difference between the two specimen in 10 subjects was $2.05 \pm 0.63 \%$ (33).

Carbon dioxide production $\left(\mathrm{CO}_{2}\right)$ during saline infusion $\left(198 \pm 8 \mathrm{ml} / \mathrm{min}\right.$ ) was not different from $\mathrm{CO}_{2}$ production during $\beta$-OHB infusion ( $196 \pm 7 \mathrm{ml} / \mathrm{min})$. Oxygen consumption was $252 \pm 10 \mathrm{ml} / \mathrm{min}$ during saline infusion and was not different from oxygen consumption during $\beta$-OHB infusions $(263 \pm 11 \mathrm{ml} / \mathrm{min})$.

Leucine flux was measured in seven subjects and leucine oxidation was measured in six subjects during both saline and sodium bicarbonate infusions. $\left[{ }^{13} \mathrm{C}\right] \mathrm{KIC}$ and ${ }^{13} \mathrm{CO}_{2}$ enrichments were in plateau between 6.5 and $8 \mathrm{~h}$, when leucine flux and leucine oxidation calculations were made (Fig. 4). Although bicarbonate infusion was associated with an increase in $\mathrm{pH}$ identical to that which occurred during $\beta-\mathrm{OHB}$ infusion, there was no effect of bicarbonate infusion on leucine kinetics (Table III).

There is significant correlation between nonoxidative portion of leucine flux and FMPS measured in seven subjects on two separate occasions (Fig. $5, r=0.8, n=14, P<0.01$ ). The increases of FMPS and nonoxidative portion of leucine flux from saline day to $\beta$-OHB day were also significantly correlated $(r=0.88, n=7, P<0.01)$.

Table II. Effect of $\beta$-Hydroxybutyrate on Leucine Kinetics

\begin{tabular}{|c|c|c|c|c|c|c|c|c|}
\hline \multirow[b]{2}{*}{ Subject } & \multicolumn{2}{|c|}{ Flux } & \multicolumn{2}{|c|}{ Oxidation } & \multicolumn{2}{|c|}{ Flux-oxidation } & \multicolumn{2}{|c|}{ Blood pH } \\
\hline & Saline & $\beta-\mathrm{OHB}$ & Saline & $\beta-\mathrm{OHB}$ & Saline & $\beta-\mathrm{OHB}$ & Saline & $\beta-\mathrm{OHB}$ \\
\hline & \multicolumn{8}{|c|}{$\mu \mathrm{mol} \cdot \mathrm{kg}^{-1} \cdot \mathrm{h}^{-1}$} \\
\hline $\mathbf{A}$ & 121.7 & 118.0 & 22.5 & 15.1 & 99.2 & 102.9 & 7.36 & 7.42 \\
\hline B & 133.6 & 134.8 & 12.4 & 9.7 & 121.2 & 125.1 & 7.40 & 7.45 \\
\hline $\mathrm{C}$ & 94.0 & 117.9 & 21.6 & 13.3 & 72.4 & 104.6 & 7.36 & 7.44 \\
\hline D & 99.0 & 108.7 & 16.3 & 13.3 & 82.7 & 95.4 & 7.39 & 7.45 \\
\hline $\mathbf{E}$ & 114.5 & 116.7 & 19.8 & 13.6 & 94.7 & 103.1 & 7.36 & 7.49 \\
\hline $\mathbf{F}$ & 115.2 & 116.9 & 21.6 & 15.6 & 93.6 & 101.3 & 7.39 & 7.48 \\
\hline $\mathbf{G}$ & 98.6 & 101.5 & 13.8 & 8.9 & 84.8 & 92.6 & 7.37 & 7.42 \\
\hline $\mathbf{H}$ & 98.6 & 96.6 & 16.5 & 9.8 & 82.1 & 86.8 & 7.39 & 7.49 \\
\hline I & 108.1 & 108.5 & 18.3 & 14.2 & 89.8 & 93.7 & 7.38 & 7.45 \\
\hline Mean & 109.3 & 113.3 & 18.1 & $12.6^{*}$ & 91.2 & $100.6^{\ddagger}$ & 7.38 & $7.45^{\ddagger}$ \\
\hline \pm SEM & 4.1 & 1.7 & 1.1 & 0.8 & 4.4 & 3.4 & 0.01 & 0.01 \\
\hline
\end{tabular}

${ }^{*}$ Less than on normal saline day $(P<0.001)$. ${ }^{\ddagger}$ Greater than on normal saline day $(P<0.02)$. 


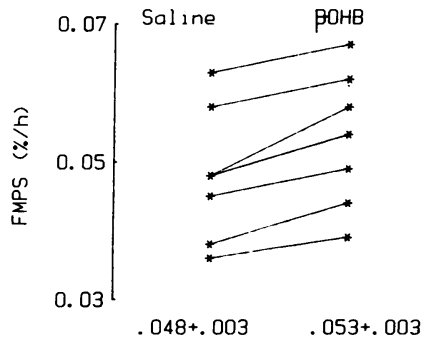

Figure 3. Fractional mixed skeletal muscle protein synthesis rate during $\beta-\mathrm{OHB}$ infusion was higher than during saline infusion $(P<0.02)$.

Amino acids. During the infusion of $\beta-\mathrm{OHB}$, there was a significant decrease in plasma concentrations of asparagine, serine, glycine, and lysine, but no change in concentrations of these amino acids during normal saline infusion (Table IV). The decrease in plasma concentrations of alanine, threonine, and tyrosine was greater during $\beta$-OHB infusion than during the normal saline infusion $(P<0.05$, Table IV). Leucine concentrations increased to the same extent $(P<0.05)$ during both saline and $\beta$-OHB infusions (Table IV). During the infusion of sodium bicarbonate, the decrease in plasma concentrations of alanine, glycine, lysine, serine, threonine, and valine was greater than during the infusion of normal saline $(P$ $<0.05$, Table $\mathrm{V})$. The changes in plasma amino acid concentrations during the bicarbonate infusion were similar to those occurring during the infusion of $\beta-\mathrm{OHB}$ (Tables IV and V). There was no significant change in the plasma concentrations of any of the amino acids between 7 and $8 \mathrm{~h}$, in any of the study groups indicating a steady state during this period.

Plasma concentrations of KIC were measured in six subjects who had normal saline and $\beta-O H B$ infusions and four subjects who had normal saline and sodium bicarbonate infusions. In the $\beta-\mathrm{OHB}$ groups, plasma KIC concentrations at 6 ,
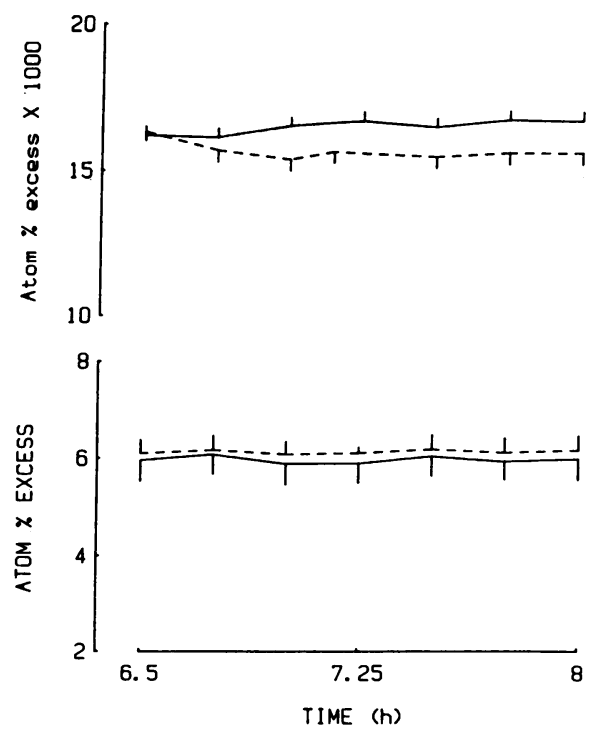

Figure 4. Expired air ${ }^{13} \mathrm{CO}_{2}$ (atom percent excess $\times 1,000$ ) during bicarbonate infusion $(|-|)$ and during saline infusion $(|---|)$ during the last $1.5 \mathrm{~h}$ is given in the upper panel and plasma $\left[{ }^{13} \mathrm{C}\right] \mathrm{KIC}$ during the same periods of bicarbonate $(|-|)$ and saline $(|---|)$ infusions are given in the lower panel.

7, 7.5, and $8 \mathrm{~h}$ were $39 \pm 7,42 \pm 8,38 \pm 6,38 \pm 7 \mu \mathrm{mol} / \mathrm{liter}$, respectively, which were not different from the plasma KIC concentrations on the corresponding time points on the control day $(36 \pm 7,38 \pm 7,38 \pm 15,39 \pm 9 \mu \mathrm{mol} / \mathrm{liter})$. On the day sodium bicarbonate was infused, plasma concentrations of KIC were $29 \pm 4,28 \pm 5,32 \pm 9,33 \pm 9 \mu \mathrm{mol} / \mathrm{liter}$, which were not different from the corresponding levels on the saline day $(25 \pm 3,28 \pm 8,29 \pm 6,25 \pm 6 \mu \mathrm{mol} / \mathrm{liter})$. Thus, during the period in which we calculated leucine kinetics, KIC concentrations in these subjects were in a steady state.

Substrates and hormones. Mean plasma concentrations of $\beta$-OHB gradually rose to $\sim 2 \mathrm{mM}$ during $\beta$-OHB infusion, but remained below $0.5 \mathrm{mM}$ during saline infusion $(P<0.01)$. Plasma concentrations of glucose and free fatty acids were lower during the $\beta$-OHB infusion than during saline infusion $(P<0.01)$. Endogenous glucose production rate during $\beta$-OHB infusion was $10.3 \pm 0.6 \mu \mathrm{mol} / \mathrm{kg} \cdot \mathrm{min}$, which was $8 \%$ lower than glucose production rate during normal saline infusion $(11.3 \pm 0.6 \mu \mathrm{mol} / \mathrm{kg} \cdot \mathrm{min}, P<0.05)$. There was no difference in the plasma concentrations of insulin, $C$-peptide, glucagon, norepinephrine, or epinephrine between $\beta-\mathrm{OHB}$ and the saline infusions (Fig. 6).

Plasma concentrations of $\beta-\mathrm{OHB}$, glucose, free fatty acids, insulin, glucagon, norepinephrine, epinephrine, and cortisol were not different between the saline and bicarbonate infusions. Endogenous glucose production rate during bicarbonate infusion $\left(12.1 \pm 0.6 \mu \mathrm{mol} / \mathrm{kg}^{-1} \cdot \mathrm{min}^{-1}\right)$ was not different from that during saline infusion $\left(11.8 \pm 0.7 \mu \mathrm{mol} / \mathrm{kg}^{-1} \cdot \mathrm{min}^{-1}\right)$.

\section{Discussion}

Plasma concentrations of $\beta-\mathrm{OHB}$ in our subjects during the infusion of sodium DL- $\beta$-OHB were much lower than concentrations observed in humans during fasting (34), or in poorly controlled, type I diabetic patients (35). This moderate increase in plasma concentrations of $\beta-\mathrm{OHB}$ was associated with a substantial $(18-41 \%)$ decrease in leucine oxidation. However, lack of any change in leucine flux indicated that proteolysis was unaffected by $\beta-O H B$ infusion, which is in agreement with a previous study (9). A decrease in leucine oxidation in conjunction with an unchanged leucine flux should either result in an elevation of plasma leucine concentrations or an increase in leucine incorporation into protein. Leucine concentrations during $\beta$-OHB infusion were not different from those in the control experiment, and leucine incorporation into skeletal muscle protein showed a small (5-17\%) but significant increase. The nonoxidative portion of leucine flux, which is theoretically an index of protein synthesis $(20,21)$, increased $10 \%$, which was similar to the average increase in leucine incorporation into skeletal muscle protein. We recently reported a significant correlation between direct measurement of mixed skeletal muscle protein synthesis rate and indirect measurement of whole-body protein synthesis (derived from nonoxidative portion of leucine flux [33]). The present study further supports the evidence that the nonoxidative portion of leucine flux is a sensitive indicator of tissue protein synthesis. Since muscle protein synthesis constitutes only $\sim 30 \%$ of wholebody protein synthesis $(33,36)$, it is probable that nonmuscle protein synthesis was also increased by $\beta-\mathrm{OHB}$.

Our finding of a decrease in leucine oxidation in humans 
Table III. Effect of Sodium Bicarbonate Infusion on Leucine Kinetics

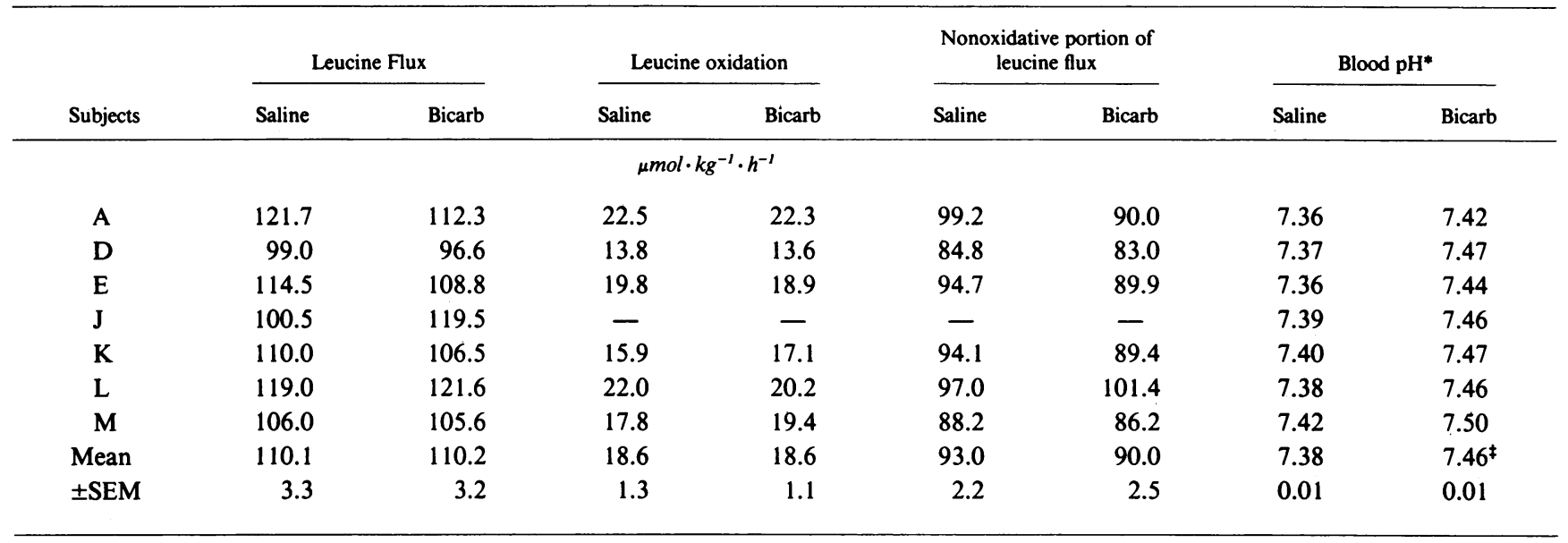

* Mean blood $\mathrm{pH}$ of three consecutive measures during the last $3 \mathrm{~h}$ is given. ${ }^{\ddagger}$ Greater than during saline infusion $(P<0.05)$.

during $\beta$-OHB infusion supports the observation that $\beta$-OHB acts as an inhibitor of ${ }^{14} \mathrm{CO}_{2}$ release from ${ }^{14} \mathrm{C}$-labeled branched chain amino acids in isolated diaphragm (37). In vitro studies, however, failed to demonstrate an increase in $\left[{ }^{14} \mathrm{C}\right]$ leucine incorporation into diaphragmatic muscle protein in the presence of $\beta$-OHB (38). On the other hand, ketoanalogues of amino acids have been shown to increase hepatic protein synthesis (30).

A small increase in blood $\mathrm{pH}$ occurred during $\beta$-OHB infusion. Since a decrease in urinary nitrogen excretion is known to occur with an increase in $\mathrm{pH}$ (39), we examined the effect of increasing $\mathrm{pH}$ on leucine kinetics by infusing sodium bicarbonate. Changes in plasma amino acid concentrations during bicarbonate infusion were similar to those that occurred during the $\beta$-OHB infusion. The plasma leucine concentration and leucine flux did not change (relative to saline infusion) during either $\beta-\mathrm{OHB}$ or sodium bicarbonate infusion. However, $\beta$-OHB infusion decreased leucine oxidation, whereas sodium bicarbonate infusion did not change leucine oxidation. Therefore the $\beta$-OHB effect on leucine oxidation is independent of $\mathrm{pH}$ changes.

Previous studies in dogs demonstrated that the inhibitory effect of ketones on free fatty acid appearance and glucose production is direct rather than mediated through changes in hormones or $\mathrm{pH}(40)$. We noticed a significant decrease in

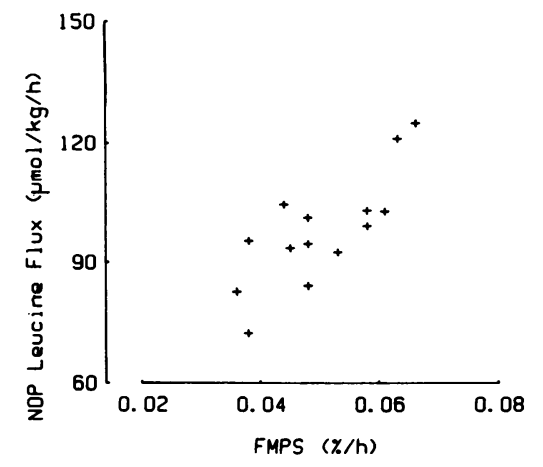

Figure 5. There is a significant correlation between fractional muscle protein synthesis rate (FMPS) and nonoxidative portion $(N O P)$ of leucine flux in seven subjects studied with and without $\beta$-OHB $(r$ $=0.8, n=14, P<0.01$ ). plasma concentration of glucose and free fatty acids during $\beta$-OHB infusion, whereas sodium bicarbonate infusion failed to change glucose or free fatty acid concentrations. We also demonstrated that the decrease in endogenous glucose production during $\beta-\mathrm{OHB}$ infusion is independent of $\mathrm{pH}$ changes. Miles et al. (9) reported a significant increase in C-peptide secretion, but no increase in insulin levels when $\beta$-OHB was infused at a rate of $15 \mu \mathrm{mol} \cdot \mathrm{kg}^{-1} \cdot \mathrm{min}^{-1}$. An infusion of $\beta$-OHB at a rate of $39 \mu \mathrm{mol} \cdot \mathrm{kg}^{-1} \cdot \mathrm{min}^{-1}$ in dogs failed to

Table IV. Effect of Saline and $\beta$-Hydroxybutyrate Infusion on Amino Acid Concentrations in 10 Subjects

\begin{tabular}{|c|c|c|c|c|}
\hline Amino acid & Infusion & Baseline value & 7-h value & 8 -h value \\
\hline & & & umol/liter & \\
\hline \multirow[t]{2}{*}{ Alanine } & Saline & $256 \pm 16$ & $211 \pm 12$ & $207 \pm 12$ \\
\hline & $\beta-\mathrm{OHB}$ & $240 \pm 20$ & $157 \pm 11^{*}$ & $147 \pm 10^{*}$ \\
\hline \multirow[t]{2}{*}{ Asparagine } & Saline & $30 \pm 2$ & $30 \pm 3$ & $29 \pm 3$ \\
\hline & $\beta-\mathrm{OHB}$ & $30 \pm 2$ & $24 \pm 3^{*}$ & $22 \pm 2^{*}$ \\
\hline \multirow[t]{2}{*}{ Glycine } & Saline & $180 \pm 17$ & $180 \pm 20$ & $181 \pm 21$ \\
\hline & $\beta-\mathrm{OHB}$ & $177 \pm 16$ & $146 \pm 16^{*}$ & $136 \pm 11^{*}$ \\
\hline \multirow[t]{2}{*}{ Leucine } & Saline & $117 \pm 6$ & $147 \pm 9$ & $146 \pm 14$ \\
\hline & $\beta$-ОНВ & $111 \pm 7$ & $150 \pm 9$ & $139 \pm 8$ \\
\hline \multirow[t]{2}{*}{ Lysine } & Saline & $165 \pm 9$ & $184 \pm 19$ & $188 \pm 19$ \\
\hline & $\beta$-ОНВ & $179 \pm 15$ & $151 \pm 15^{*}$ & $159 \pm 12$ \\
\hline \multirow[t]{2}{*}{ Phenylalanine } & Saline & $50 \pm 2$ & $47 \pm 2$ & $46 \pm 2$ \\
\hline & $\beta$-ОНВ & $47 \pm 2$ & $42 \pm 2$ & $40 \pm 2^{*}$ \\
\hline \multirow[t]{2}{*}{ Serine } & Saline & $110 \pm 5$ & $112 \pm 6$ & $110 \pm 6^{*}$ \\
\hline & $\beta-\mathrm{OHB}$ & $107 \pm 4$ & $81 \pm 4^{*}$ & $78 \pm 3$ \\
\hline \multirow[t]{2}{*}{ Threonine } & Saline & $133 \pm 8$ & $121 \pm 7$ & $117 \pm 8$ \\
\hline & $\beta$-ОНB & $127 \pm 6$ & $100 \pm 8^{*}$ & $97 \pm 5^{*}$ \\
\hline \multirow[t]{2}{*}{ Tyrosine } & Saline & $48 \pm 4$ & $40 \pm 3$ & $40 \pm 4$ \\
\hline & $\beta$-ОНВ & $47 \pm 4$ & $35 \pm 2^{*}$ & $33 \pm 3^{*}$ \\
\hline \multirow[t]{2}{*}{ Valine } & Saline & $206 \pm 10$ & $190 \pm 11$ & $193 \pm 12$ \\
\hline & $\beta-\mathrm{OHB}$ & $197 \pm 9$ & $181 \pm 16$ & $173 \pm 12^{*}$ \\
\hline
\end{tabular}

${ }^{*} P<0.05$ compared to mean at same time during saline infusion. 
Table V. Effect of Saline and $\mathrm{Na} \mathrm{HCO}_{3}$ Infusion on Amino Acid Concentrations in Six Subjects

\begin{tabular}{|c|c|c|c|c|}
\hline Amino acid & Infusion & $\begin{array}{l}\text { Baseline } \\
\text { value }\end{array}$ & $\begin{array}{c}\text { 7-h value } \\
(n=5)\end{array}$ & 8 -h value \\
\hline & & \multicolumn{3}{|c|}{ umol/liter } \\
\hline \multirow[t]{2}{*}{ Alanine } & Saline & $241 \pm 23$ & $201 \pm 20$ & $199 \pm 20$ \\
\hline & Bicarb & $265 \pm 26$ & $178 \pm 27$ & $163 \pm 22^{*}$ \\
\hline \multirow[t]{2}{*}{ Asparagine } & Saline & $30 \pm 4$ & $32 \pm 4$ & $31 \pm 3$ \\
\hline & Bicarb & $39 \pm 5^{*}$ & $34 \pm 3$ & $31 \pm 4$ \\
\hline \multirow[t]{2}{*}{ Glycine } & Saline & $181 \pm 29$ & $195 \pm 34$ & $182 \pm 28$ \\
\hline & Bicarb & $168 \pm 20$ & $152 \pm 13$ & $144 \pm 19^{*}$ \\
\hline \multirow{2}{*}{ Leucine } & Saline & $123 \pm 8$ & $152 \pm 7$ & $165 \pm 10$ \\
\hline & Bicarb & $124 \pm 11$ & $148 \pm 18$ & $145 \pm 15$ \\
\hline \multirow[t]{2}{*}{ Lysine } & Saline & $164 \pm 13$ & $183 \pm 35$ & $180 \pm 28$ \\
\hline & Bicarb & $164 \pm 12$ & $145 \pm 14$ & $144 \pm 14$ \\
\hline \multirow[t]{2}{*}{ Phenylalanine } & Saline & $49 \pm 2$ & $45 \pm 3$ & $45 \pm 3$ \\
\hline & Bicarb & $52 \pm 4$ & $48 \pm 5$ & $44 \pm 5$ \\
\hline \multirow[t]{2}{*}{ Serine } & Saline & $107 \pm 9$ & $112 \pm 10$ & $109 \pm 9$ \\
\hline & Bicarb & $107 \pm 10$ & $94 \pm 8$ & $88 \pm 9^{*}$ \\
\hline \multirow[t]{2}{*}{ Threonine } & Saline & $125 \pm 12$ & $117 \pm 14$ & $113 \pm 10$ \\
\hline & Bicarb & $120 \pm 16$ & $93 \pm 13^{*}$ & $91 \pm 13^{*}$ \\
\hline \multirow[t]{2}{*}{ Tyrosine } & Saline & $53 \pm 7$ & $40 \pm 6$ & $42 \pm 6$ \\
\hline & Bicarb & $61 \pm 8$ & $47 \pm 7$ & $45 \pm 6$ \\
\hline \multirow[t]{2}{*}{ Valine } & Saline & $208 \pm 16$ & $196 \pm 9$ & $211 \pm 14$ \\
\hline & Bicarb & $229 \pm 17$ & $204 \pm 21$ & $192 \pm 19$ \\
\hline
\end{tabular}

* $P<0.05$ compared to mean at same time during saline infusion.

increase plasma insulin levels but increased plasma glucagon (40). However, small physiological increases in plasma $\beta-O H B$ are not associated with any changes in insulin or glucagon levels $(40,41)$. Our subjects showed no significant change in their plasma concentrations of insulin, C-peptide, glucagon, epinephrine, norepinephrine, or cortisol. If increased insulin secretion occurred, one would have expected a decrease in leucine flux, since leucine flux is more sensitive to insulin than leucine oxidation (42-44). $\beta-\mathrm{OHB}$ does not increase insulin sensitivity in man (45). It appears therefore, that changes in leucine oxidation, plasma concentrations of free fatty acids and glucose occurring during $\beta$-OHB infusion are independent of the various hormones that we assayed.

A protein sparing effect of $\beta-\mathrm{OHB}$ has been demonstrated in subjects fasted for several days (4). We studied subjects in their postabsorptive state whose hormonal profile was different from the subjects fasted for several days (2). We chose to increase blood concentrations of postabsorptive subjects (usually low) rather than further increase an already elevated blood $\beta$-OHB level in fasted subjects. The observed decrease in leucine oxidation and protein synthesis in our subjects indicated that the effect of $\beta-\mathrm{OHB}$ on protein in the fasted subjects may not depend on the hormonal changes during fasting.

Another important observation from our study is that one cannot make any meaningful conclusions about metabolism of amino acids based on plasma concentrations alone. In our subjects plasma leucine concentrations were not affected by $\beta$-OHB whereas leucine oxidation and leucine incorporation into protein were clearly affected by $\beta$-OHB. Based on plasma concentrations alone, one might falsely conclude that $\beta-\mathrm{OHB}$ has no effect on amino acid metabolism independent of $\mathrm{pH}$ changes.

In summary, we conclude that a small physiological increase in $\beta$-OHB concentrations decreases leucine oxidation and enhances incorporation of leucine into muscle protein in humans. These data indicate that reduced amino acid oxida-
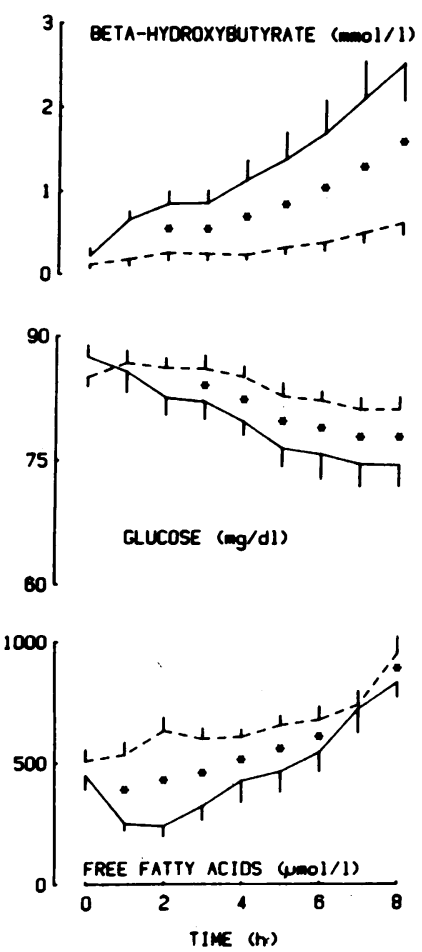
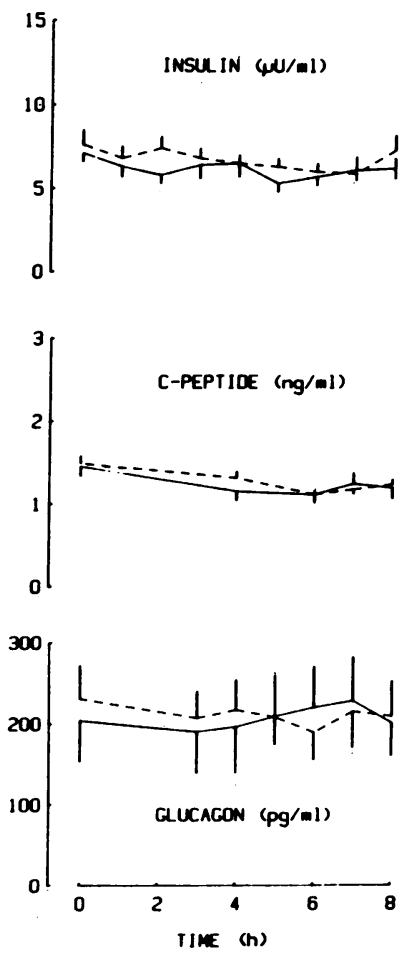
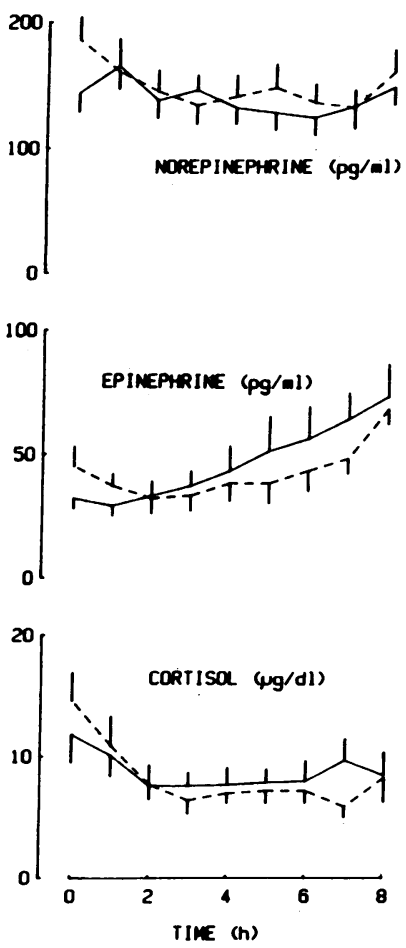

Figure 6. Plasma concentrations of substrates and hormones during saline $(|---|)$ and $\beta-\mathrm{OHB}(|-|)$ infusions. Abbreviation: 1 , liter. 
tion and enhanced protein synthesis are at least partially responsible for nitrogen conservation during $\beta$-OHB infusion.

\section{Acknowledgments}

We are grateful to Elaine King, Kirti Bhatt, and Charles Ford for their technical support; the Clinical Research Center nursing staff and Marcia Craig Statt for help with the studies; and Nancy A. Needler for typing the manuscript.

This study was supported by grants AM-20494, RR-00044, RR-00047, and RR-05403 from the National Institutes of Health and File No. 186533 of the Juvenile Diabetes Foundation.

\section{References}

1. Benedict, F. G. 1915. A Study of Prolonged Fasting. Carnegie Institutions of Washington, Washington, DC.

2. Cahill, G. F. Jr. 1970. Starvation in man. N. Engl. J. Med. 282:668-675.

3. Owen, O. E., H. G. Morgan, J. M. Kemp, H. G. Sullivan, M. G. Herrera, and G. F. Cahill Jr. 1968. Brain metabolism during fasting. $J$. Clin. Invest. 46:1589-1595.

4. Sherwin, R. S., R. G. Hendler, and P. Felig. 1975. Effect of ketone infusions on amino acid and nitrogen metabolism in man. $J$. Clin. Invest. 55:1382-1390.

5. Miles, J. M., M. H. Haymond, and J. E. Gerich. 1981. Suppression of glucose production and stimulation of insulin secretion by physiological concentrations of ketone bodies in man. J. Clin. Endocrinol. Metab. 52:34-37.

6. Muller, M. J., U. Paschen, and H. J. Seitz. 1984. Effect of ketone bodies on glucose production and utilization in the miniature pig. $J$. Clin. Invest. 74:249-261.

7. Pawan, G. L. S., and S. J. G. Semple. 1983. Effect of 3-hydroxybutyrate in obese subjects on very-low-energy diets and during therapeutic starvation. Lancet. $i: 15-17$.

8. Williamson, D. H., R. Farrell, A. Kerr, and R. Smith. 1977. Muscle-protein catabolism after injury in man, as measured by urinary excretion of 3-methylhistidine. Clin. Sci. Mol. Med. 52:527-533.

9. Miles, J. M., S. L. Nissen, R. A. Rizza, J. E. Gerich, and M. W. Haymond. 1983. Failure of infused beta-hydroxybutyrate to decrease proteolysis in man. Diabetes. 32:197-205.

10. Abumrad, N. N., D. Rabin, M. P. Diamond, and W. W. Lacey. 1981. Use of heated superficial hand vein as an alternative site for the measurement of amino acid concentrations and for the study of glucose and alanine kinetics in man. Metab. Clin. Exp. 30:936-940.

11. Edwards, R. H. T., A. Young, and M. Wiles. 1980. Needle biopsy of skeletal muscle in the diagnosis of myopathy and the clinical study of muscle function and repair. N. Engl. J. Med. 302:261-271.

12. Welle, S. L., and R. G. Campbell. 1986. Decrease in resting metabolic rate during rapid weight loss is reversed by low dose thyroid hormone replacement. Metab. Clin. Exp. 35:289-291.

13. Ford, G. C., K. N. Cheng, and D. Halliday. 1985. The analysis of $\left[1-{ }^{13} \mathrm{C}\right]$ leucine and $\left[{ }^{13} \mathrm{C}\right] \mathrm{KIC}$ in plasma by capillary gas chromatography/mass spectrometry in protein turnover studies. Biomed. Mass Spectrom. 12:432-436.

14. Halliday, D., and W. W. C. Read. 1981. Mass spectrometric assay of stable isotopic enrichment for the estimation of protein turnover in man. Proc. Nutr. Soc. 40:321-334.

15. Read, W. W. C., M. A. Read, M. J. Rennie, R. C. Griggs, and D. Halliday. 1984. Preparation of $\mathrm{CO}_{2}$ from blood and protein-bound amino acid carboxyl groups for quantification and ${ }^{13} \mathrm{C}$-isotope measurements. Biomed. Mass Spectrom. 11:348-352.

16. Wolfe, R. R., R. D. Goodenough, M. H. Wolfe, G. T. Royle, and E. R. Nadel. 1982. Isotopic analysis of leucine and urea metabolism in exercising humans. J. Appl. Physiol. 52:458-466.

17. Rennie, M. J., R. H. T. Edwards, D. Halliday, D. E. Matthews, S. L. Wolman, and D. J. Millward. 1982. Muscle protein synthesis measured by stable isotope techniques in man.: the effects of feeding and fasting. Clin. Sci. 63:519-523.

18. Vazquez, J. A., H. S. Paul, and S. A. Adibi. 1986. Relation between plasma and tissue parameters of leucine metabolism in fed and starved rats. Am. J. Physiol. 250:E615-E621.

19. Schwenk, W. F., B. Beaufrere, and M. W. Haymond. 1985. Use of reciprocal pool specific activities to model leucine metabolism in man. Am. J. Physiol. 249:E646-E650.

20. Nair, K. S., J. S. Garrow, G. C. Ford, R. F. Mahler, and D. Halliday. 1983. Effect of poor diabetic control and obesity on whole body protein metabolism in man. Diabetologia. 25:400-403.

21. Matthews, D. E., K. J. Motil, D. K. Rohrbaugh, J. F. Burke, V. R. Young, and D. M. Bier. 1980. Measurement of leucine metabolism in man from a primed, continuous infusion of $\mathrm{L}-\left[1-{ }^{13} \mathrm{C}\right] l$ leucine. Am. J. Physiol. 238:E473-E479.

22. Bier, D. M., K. J. Arnold, W. R. Sherman, W. H. Holland, W. F. Holmes, and D. M. Kipnis. 1977. In vivo measurement of glucose and alanine metabolism with stable isotopic tracers. Diabetes. 26:1005-1015.

23. Kelley, J., W. S. Stirewalt, and L. Chrin. 1984. Protein synthesis in rat lung: measurements in vivo based on leucyl t RNA and rapidly turning-over Procollagen I. Biochem. J. 222:77-83.

24. Low, R. B., W. S. Stirewalt, S. R. Rittling, and R. C. Woodworth. 1984. Amino acid pools in cultured muscle cells. J. Cell. Biochem. 25:123-129.

25. Martin, A. F., M. Rabinowitz, R. Blough, G. Prior, and R. Zak. 1977. Measurements of half-life of rat cardiac myosin heavy chain with leucyl-t-RNA used as a precursor pool. J. Biol. Chem. 252:3422-3429.

26. Williamson, D. H., J. Mellanby, and H. A. Krebs. 1962. Enzymatic determination of $\mathrm{D}(-)$ beta-hydroxybutyric acid and acetoacetic acid in blood. Biochem. J. 82:90-96.

27. Trout, D. L., E. H. Estes, and S. J. Friedberg. 1960. Titration of free fatty acids in plasma: a study of current methods and new modification. J. Lipid Res. 1:199-202.

28. Faloona, G., and R. Unger. 1974. Glucagon. In Methods of Hormone Radioimmunoassay. B. Jaffe and H. Behrman, editors. Academic Press, Inc. New York. 317-328.

29. Heding, L. G. 1975. Radioimmunological determination of C-peptide in serum. Diabetologia. 11:541-548.

30. Lilavivathana, U., R. G. Brodows, P. D. Woolf, and R. G. Campbell. 1979. Counterregulatory hormonal responses to rapid glucose lowering in diabetic man. Diabetes. 28:873-877.

31. Hill, D. W., F. H. Walter, T. D. Wilson, and J. D. Stuart. 1979. High performance liquid chromatographic determination of amino acids in the picomole range. Anal. Chem. 51:1338-1341.

32. Winer, B. J. 1971. Statistical Principles in Experimental Design. 2nd edition McGraw-Hill Book Company, New York.

33. Nair, K. S., D. Halliday, and R. C. Griggs. 1988. Leucine incorporation into mixed skeletal muscle protein in humans. Am. J. Physiol. 254:E208-E213.

34. Cahill, G. F., Jr., M. G. Herrera, A. P. Morgan, J. S. Soeldner, J. Steinke, P. L. Levy, G. A. Richard Jr., and P. M. Kipnis. 1966. Hormone-fuel interrelationships during fasting. J. Clin. Invest. 45:17511769.

35. Nair, K. S., D. Halliday, and J. S. Garrow. 1984. Increased energy expenditure in poorly controlled type I diabetes. Diabetologia. 27:13-16.

36. Lobley, G. E., V. Milne, J. M. Lovie, P. J. Reeds, and K. Pennie. 1980. Whole body and tissue protein synthesis in cattle. Br.J. Nutr. 43:491-502.

37. Buse, M. G., J. F. Biggers, K. H. Friderici, and J. F. Buse. 1972. 
Oxidation of branched chain amino acids by isolated hearts and diaphragms of the rats. J. Biol. Chem. 247:8085-8096.

38. Buse, M. G., and J. F. Buse. 1967. Effect of free fatty acids on protein synthesis and amino acid metabolism of isolated rat diaphragms. Diabetes. 16:753-764.

39. Fery, F., and E. O. Balasse. 1980. Differential effects of sodium acetoacetate and acetoacetic acid infusions on alanine and glutamine metabolism in man. J. Clin. Invest. 66:323-331.

40. Shaw, J. H. F., and R. R. Wolfe. 1984. Influence of beta-hydroxybutyrate infusion on glucose and free fatty acid metabolism in dogs. Am. J. Physiol. 247:E756-E764.

41. Krish, R. E., L. O. C. Frith, and S. J. Saunders. 1976. Stimulation of albumin synthesis by ketoanalogues of amino acids. Biochim. Biophys. Acta. 442:437-441.

42. Nair, K. S., G. C. Ford, and D. Halliday. 1987. Effect of intrave- nous insulin treatment on in vivo whole body leucine kinetics and oxygen consumption in insulin-deprived type I diabetic patients. Metab. Clin. Exp. 36:491-495.

43. Fukagawa, N. K., K. L. Minaker, J. W. Rowe, M. N. Goodman, D. E. Matthews, D. M. Bier, and V. R. Young. 1985. Insulin-mediated reduction of whole body protein breakdown: dose-response effects on leucine metabolism in postabsorptive men. J. Clin. Invest. 76:23062311.

44. Umpleby, A. M., M. A. Boroujerdi, P. M. Brown, E. R. Carson, and P. H. Sonkson. 1986. The effect of metabolic control on leucine metabolism in type I diabetic patients. Diabetologia. 29:131-141.

45. Bratusch-Marrain, P. R., and R. A. DeFronzo. 1986. Failure of hyperketonemia to alter basal and insulin-mediated glucose metabolism in man. Horm. Metab. Res. 18:185-189. 